UDC 658.511

M. Maksymov ${ }^{1}$,

K. Beglov ${ }^{1}$, PhD, Assoc. Prof.,

O. Maksymova ${ }^{2}, \mathrm{PhD}$, Assoc. Prof.,

O. Maksymov ${ }^{1}$

${ }^{1}$ Odessa National Polytechnic University, 1 Shevchenko Ave., Odessa, Ukraine, 65044; e-mail: maximov.agro@gmail.com,

beglovkv@gmail.com,m.alex.m11@gmail.com

${ }^{2}$ Odessa National Academy of Food Technologies, 112 Kanatna Str., Odesa, Ukraine, 65039; e-mail: oxana.b@gmail.com

\title{
THE METHOD OF FINDING THE MOST NATURAL STRUCTURE OF A BIOTANK POWER PLANT
}

\begin{abstract}
М.М. Максимов, К.В. Беглов, О.Б. Максимова, О.М. Максимов. Метод пошуку найкращої структури біотенкової енергетичної установки. Критерієм вибору найкращої установки є різниця приведених витрат розглянутого і базового варіантів. Такий метод пошуку залежить тільки від кон'юнктури і не відображає реальних витрат і абсолютно не враховує показники ефективності. Метою роботи була розробка методу пошуку найкращої структури біотенкової енергетичної установки для підтримки балансу енергетичної системи. Імітаційними методами моделювання було розроблено автоматизовану системи керування установкою перолізу для утилізації збродженого залишку, який отримують в біогазовій технології. Це дозволило виробляти додатково продукт-газ з максимальною теплотворною здатністю. Було визначенно цільову функцію оптимізації для знаходження найкращих структурних комбінацій енергетичної установки, що використовує відновлювальні джерела енергії, які мають властивість регулювання, в залежності від зовнішніх збурень з метою підтримання балансу енергосистеми. В результаті розробки коп'ютерно-інтегровані системи керування біотенковою технологією була визначена найкраща структура енергетичних установок. Ця структура складеться з біореактора який працює в стаціонарному режимі і установок піролізу та паротурбінної установки, які працюють в регульованих динамічних діапазонах. Отриманий біометан і продукт-газ з установки піролізу направляється в газгольдер а потім на дизельгенераторну установку. Вуглистий залишок і смоли надходять на склад, а потім направляються на паротурбінну установку. Регулюючи роботу установок піролізу і паротурбінних змінюється вироблення на газовому дизелі електричної енергії та і додатково змінюється вироблення електричної енергії на паротурбінній установці, при цьому паротурбінна установка не навантажується до максимального значення, а має обертовий запас під резерв, показник ефективності найкращої структури становить 0,4112 .

Ключові слова: найкраща структура, біотенкова енергетична кстановка, керований пероліз, регульовані динамічні діапазони

M. Maksymov, K. Beglov, O. Maksymova, O. Maksymov. The method of finding the most natural structure of a biotank power plant. The criterion for choosing the best plant is the difference between gross costs and the baseline options. This search method depends only on the situation and does not reflect the real costs and does not completely take into account the performance indicators. The purpose of the work was to develop a method of finding the best structure of a biotank power plant to maintain the balance of the energy system. Simulated methods of simulation have developed an automated control system for the plant of perolysis for the utilization of fermented residues, which are obtained in biogas technology. This made it possible to produce additional product-gas with maximum calorific value. An optimization target function has been identified to find the best structural combinations of a power plant that uses controllable renewable energy sources, depending on external perturbations, to maintain power system balance. As a result of development of the computer-integrated control systems, the best structure of power plants was determined by biotank technology. This structure will consist of a steady-state bioreactor and pyrolysis and steam turbine facility units operating in controlled dynamic ranges. The resulting biomethane and product gas from the pyrolysis facility is sent to the gas holder and then to the diesel generating facility. The carbonaceous residue and resins are fed into the warehouse and then sent to the steam turbine facility. By regulating the operation of the pyrolysis and steam turbine facility, the production of gas diesel electricity is changed, and the power generation at the steam turbine facility is further changed, while the steam turbine facility is not loaded to its maximum value and has a rotating reserve, the efficiency of the best structure is 0.4112 .

Keywords: the best structure, biotank power plant, controlled perolysis, adjustable dynamic ranges
\end{abstract}

\section{Introduction}

To find the best indicators of power plants, the system operator uses a target function, which is based on the minimization of gross costs, which allows to compare options that have the similar beneficial effect, but different specific indicators [1]. With various useful effects, the closing function is introduced into the objective function by the value of the difference in the useful effect. The criterion for choosing the best installation is the difference in the gross costs of the considered and basic options. This approach depends only on the conjuncture and does not reflect real costs and absolutely

\section{DOI: 10.15276/opu.1.60.2020.09}

(C) 2020 The Authors. This is an open access article under the CC BY license (http://creativecommons.org/licenses/by/4.0/). 
does not take into account the efficiency indicators of that group of plants, which can be and have minimal costs [2]. The value of the objective function of optimizing the efficiency of the technical and economic method is not "limited" and does not allow us to assess the influence of certain processes on the overall efficiency of the option.

\section{Analysis of literary sources and definition of research problems}

Previously reviewed material suggests that for finding the best structure of any power plant, at the moment, there is no single approach to considering efficiency, taking into account both energy and economic criteria in the target functions.

An analysis of literary sources showed that relative energy performance indicators can be used to find the best structure for any power plant.

The expressions showed in [3] using the above criteria do not give satisfactory results. Moreover, based on such expressions, it is impossible to determine the deficit of one type of energy production and the overproduction of another type in the system. However, with a different approach, it is recommended to use technical and economic or other specific indicators to form the objective function $[3,4]$.

In [5], formation of performance indicators is proposed to be carried out in close connection with the energy system. At the same time, the control surface includes the energy system, the unit under analysis, and the environmental emission rating system.

Materials $[4,5]$ of research have shown that the optimization of power plants is carried out according to some parameter or group of parameters. And the method of writing such an objective function is quite simple. Quick amendment is being made in the amount of energy products consumed in the system. In general, more than one plant works in the system. In $[4,5]$ there is no description of the method for finding the best structure of any power plant, although the objective function is shown that allows performing structural optimization.

An analysis of the sources showed that in the open literature there is no method for finding the best structure for a power plant, which allows you to determine the production of energy products depending on the system demand and disturbances. Therefore, it is necessary to develop methods for finding the best structures to ensure the efficient operation of power plants in the system.

\section{Aims and objectives of the research}

The purpose of the article is to develop a method of finding the best structure of a biotank power plant that uses renewable energy sources to maintain the balance of the energy system by finding the best structure of its components, while improving its energy efficiency.

The goal is accomplished by solving the following tasks:

- development of a model of automated control system for the utilization of fermented residue of variable composition, which is obtained in biogas technology, which will allow to produce additional synthesis gas with maximum calorific value;

- development of a method for determining the objective function of optimization and finding the best structural combinations of energy plant using renewable energy sources, which have the property of regulation, depending on external perturbations in order to maintain the balance of the power system.

\section{Model of automated control system for disposal of fermented residue}

Let's consider the control object, which is a biotenk power plant, shown in Fig. 1. The prototype plant, considered in [6]. the second section, implements the following technology. The vegetable substrate from the storage (1) enters the preparation point (2), then by the pump (3) feed the prepared raw material loaded into the methane tank (4). Fermentation biogas enters the gas holder (5) and then to the diesel generator facility (DGF) (6). To heat the raw material in the metatank to the fermentation temperature and maintain the thermal regime, use a cooling circuit (DGF) (7) through which hot water flows. The fermented residue enters the storage (8). The circuit under consideration has two control 
loops. In the first circuit, regulating the flow of gas from the metatank to the gas holder, with the flow rate of the digested residue correction, the consumption of the loaded substrate in the metatank is determined. The second control loop maintains the set temperature in the metatank due to the heat dissipated from the DGF by the flow of coolant. In this condition, the plant operates in a stationary mode without stops, which is a consequence of the large inertia of the raw material control channel 4 [6].

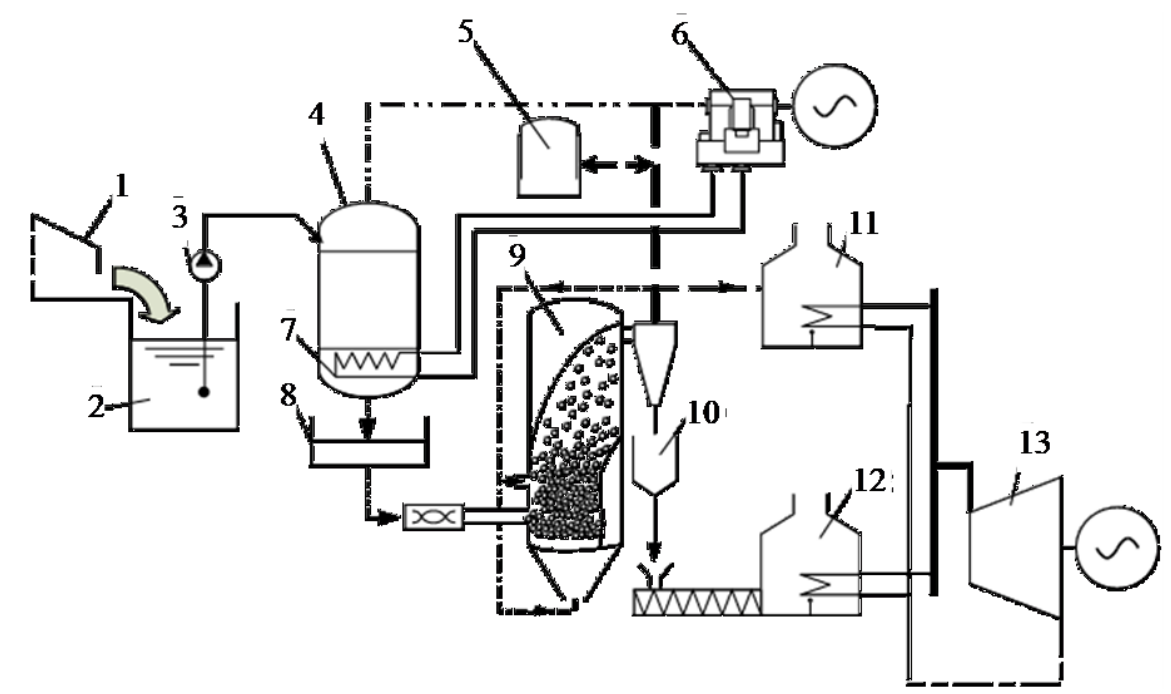

Fig. 1. Technological scheme of bioten power plant

To increase energy efficiency and acquire maneuvering properties, it is proposed to add the biogas plant with pyrolysis plant. The pyrolysis plant can operate cyclically or amend its gas productivity depending on the adopted strategy. The pyrolysis reactor (9) receives the dried fermented residue from the storage (8).

The produced product gas at the outlet from the reactor enters the general system, where it is divided into two streams: to the consumer and to recirculation. The last one is fed to the recirculation inlet of the reactor and serves to dry and heat the raw material. The amount of air required for pyrolysis is supplied through the air collector. The resulting carbonaceous residue and resins are sent to the warehouse (10).

For the pyrolysis installation, the adjustable parameters are:

- gas product consumption;

- pyrolysis temperature (of gas product);

- gas product composition.

Control actions are:

- consumption of raw material;

- air consumption;

- consumption of product gas recirculation.

External disturbances to the object are:

- predetermined consumption of product gas;

- composition of the raw material.

The presence of a "wet" gas tank allows you to have a buffer tank to smooth the flow of gas in case of sharp changes in its consumption. In addition, a amendment in the level in the gas tank can serve as yet another controlled parameter that shows an imbalance between the consumed and generated amount of the gas product.

The control system is constructed as follows. There are three controllers in the system. The required product gas flow rate is determined by the deviation of the water level in the gas tank and is maintained by amendment the product gas recirculation consumption. However, without maintaining 
the required mass of the substance in the reactor, product gas generation will cease, therefore, the pyrolysis reactor should be equipped with a product gas flow regulator that amend the consumption of raw material (fermented residue). The pyrolysis temperature is maintained by amendment the air flow. To compensate for disturbances in the composition of the raw material, the temperature controller receives a correction signal for the composition of the product gas.

In addition, to create a power reserve and increase energy efficiency and improve the maneuverability of the installation, it is proposed to additionally equip it with a steam turbine facility. The steam turbine unit includes a steam boiler (11) and a steam turbine (13). The steam boiler (11) can operate on carbonaceous residue and tar liquid fractions. The presence of reserves of carbonaceous residue allows you to use it as the main fuel for the operation of the steam power plant in the mode of providing power changes. In this case, the turbine operates at partial power. And resins, as a higher-calorie fuel, can be used to cover peak loads of energy consumption in case of lack of power from diesel generator facility. In this case, the turbine (13) is brought to maximum power. DGF (6) from metaten gas works with a large reserve of power which decreases when the gas product is generated at the pyrolysis unit (9), thereby allowing DGF (6) to partially participate in the power coating.

The block diagram of the modernized plant is shown at Fig. 2. Designations of structures correspond to the description to Fig. 1.

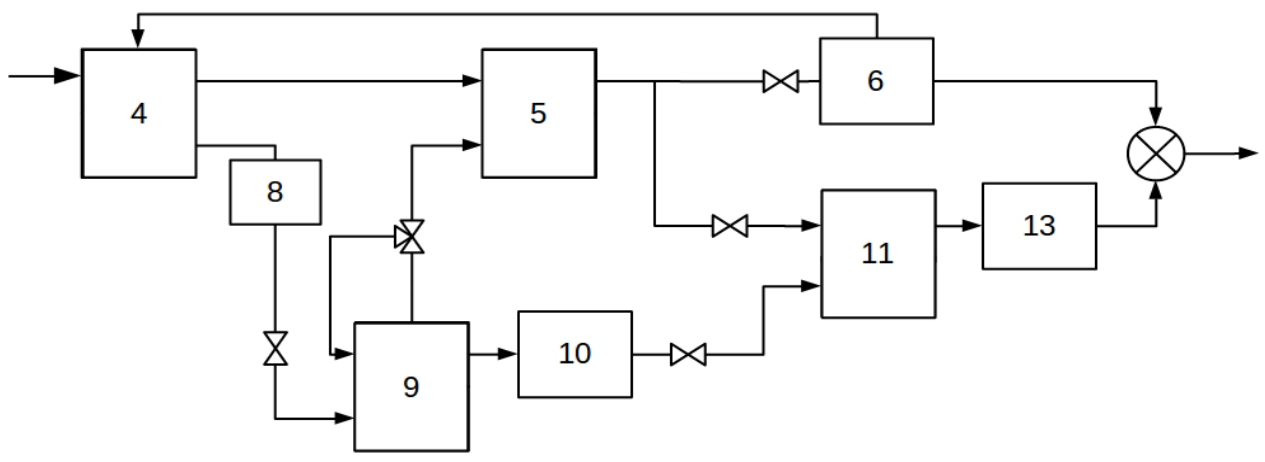

Fig. 2. The block diagram of the bioten energy plant

For research transient characteristics of the bioten power plant operation, the a simulation model was compiled. Enlarged, it consists of models of a bioreactor [6], coal boilers [7] and a turbogenerator [8], a diesel generator [9] of a pyrolysis unit [10].

Mathematical models of most elements are known and considered in the relevant literature [7, 8, $9,10]$. The mathematical model $[11,12]$ of the pyrolysis unit is considered. The structural diagram of the model is shown in Fig. 3.

From the point of view of biogas production control, the bioreactor has a sufficiently large inertia and is not used for operational control the power of power plant. Therefore, the dynamic model of the bioreactor is not considered further.

After consideration of the external disturbances, adjustable and control parameters, automated control system of bioten energy plant was synthesized. The scheme of the automated control system in simulation environment Simulink is shown at Fig. 4.

To research the operation of the ACS as external influences, a amendment in the power setting of the plant was chosen, when the boiler is running on gas ZNgen $=50 \%$ and when the boiler is on carbonaceous residue ZNgen $1=30 \%$.

The amount of carbon residue is calculated as the difference between the molar flow rates of the raw material and gas synthesis (coal = G1-Q2)

Transient graphs of ACS are shown in Fig. 5 and Fig. 6. 


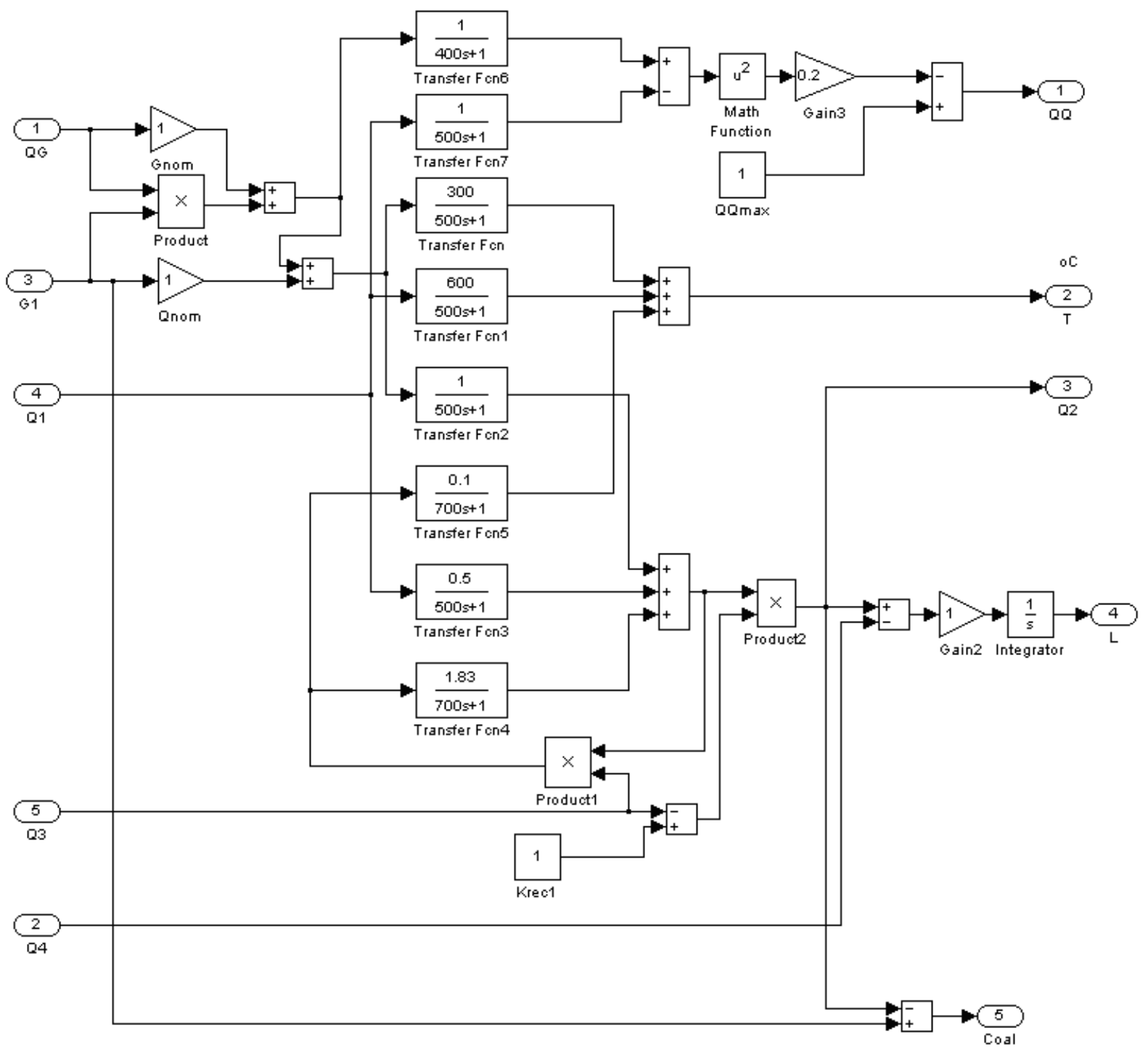

Fig. 3. Block diagram of a simulation model of a pyrolysis facility

Thus, a preliminary simulation of each individual unit of power equipment allowed to obtain its transient characteristics. This made it possible to determine the times of transitional processes.

In the Table 1 shown the initial data for calculating the possible structures of a bioten power plant.

\section{Method for finding the best plant structure}

Let's consider the method of finding the best structure of a biotank power plant for the possibility of primary regulation of the power system. Primarily, the need for electric energy $N(\tau)$ in a given time range $\tau \in\left[0 ; \tau_{\text {est }}\right]$ should be known. Secondly, the types of power plants that can be included in the structure under consideration should be known. Their minimum and maximum power $N_{j}^{\min }$ and $N_{j}^{\max }$ and operating mode (stationary $N_{j}(\tau)=$ const, dynamic $N_{j}(\tau)=$ var with possible stops and fast starts). For the conditions under consideration, the bioreactor operates in a stationary mode $Q_{b m}=$ const . The product gas pyrolysis plant operates in a dynamic mode $G_{p g}(\tau)=$ var, but without stops. 
STF operates in dynamic mode $N_{\text {STF }}\left(\tau_{i}\right)$ but with the ability to create a spinning reserve in a virtual plant $N_{\text {VirPP }}\left(\tau_{i}\right)$. Thus, for each type of plant, a vector $\bar{l}$ of source data is set, which includes: maximum power ( $N_{j}^{\max }$ ) and its corresponding efficiency $\eta_{j}\left(N_{j}\left(\tau_{i}\right)\right.$ ), minimum power $N_{j}^{\min }$, dynamic characteristic of the transient process along the channel fuel generated electricity $N_{j} \in\left[N_{j}^{\min } ; N_{j}^{\max }\right]$, the output characteristic is system efficiency $\eta_{e f j}$, which is calculated according to $[3,4,5]$ of the following form $\bar{l}=\left(N_{j}^{\max }, \eta_{j}\left(N_{j}\right), N_{j}^{\min }, N_{j} ; \eta_{\text {ef } j}\right)$.

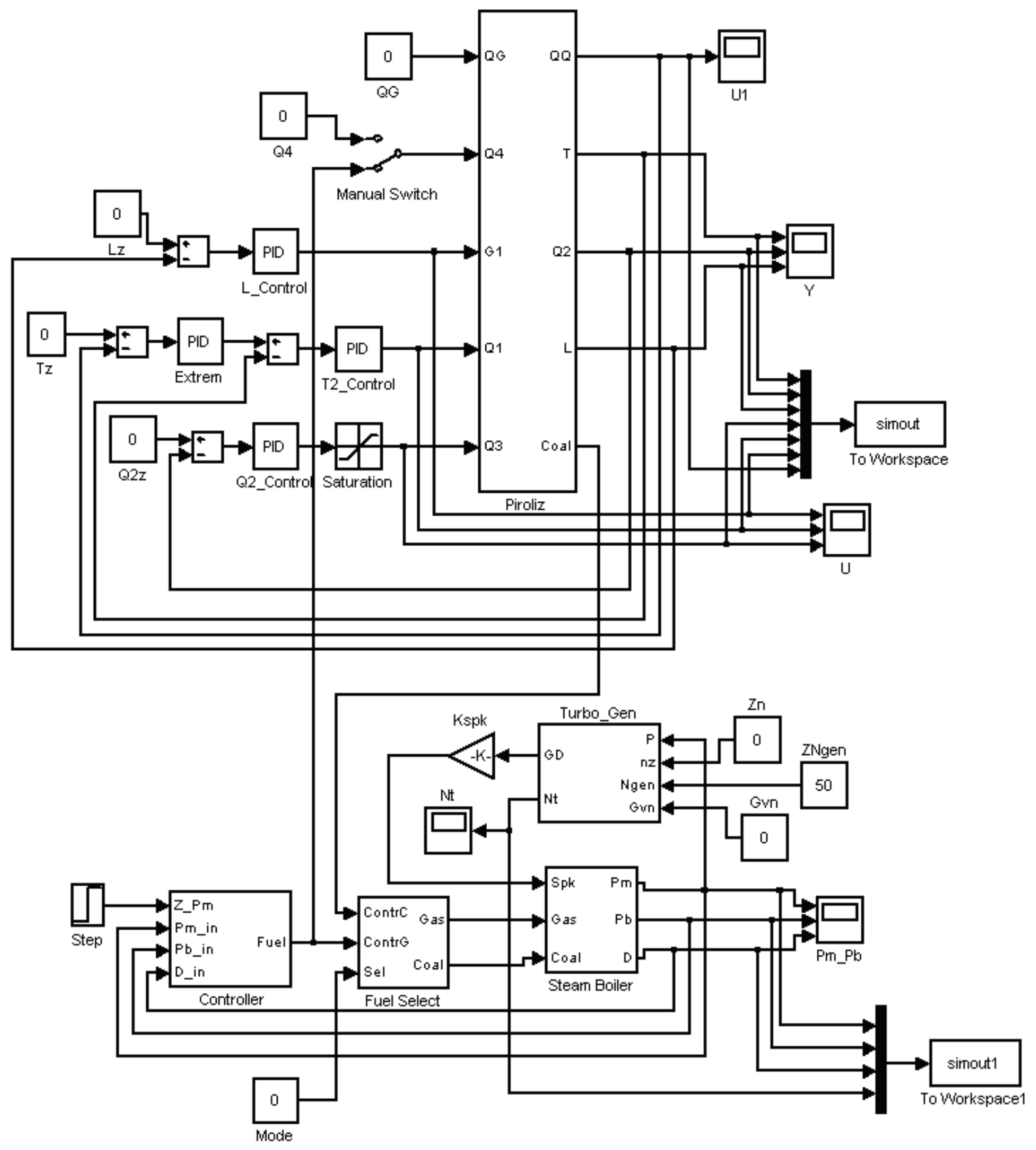

Fig. 4. Model of a pyrolysis facility with a boiler loaded with a turbo generating facility 

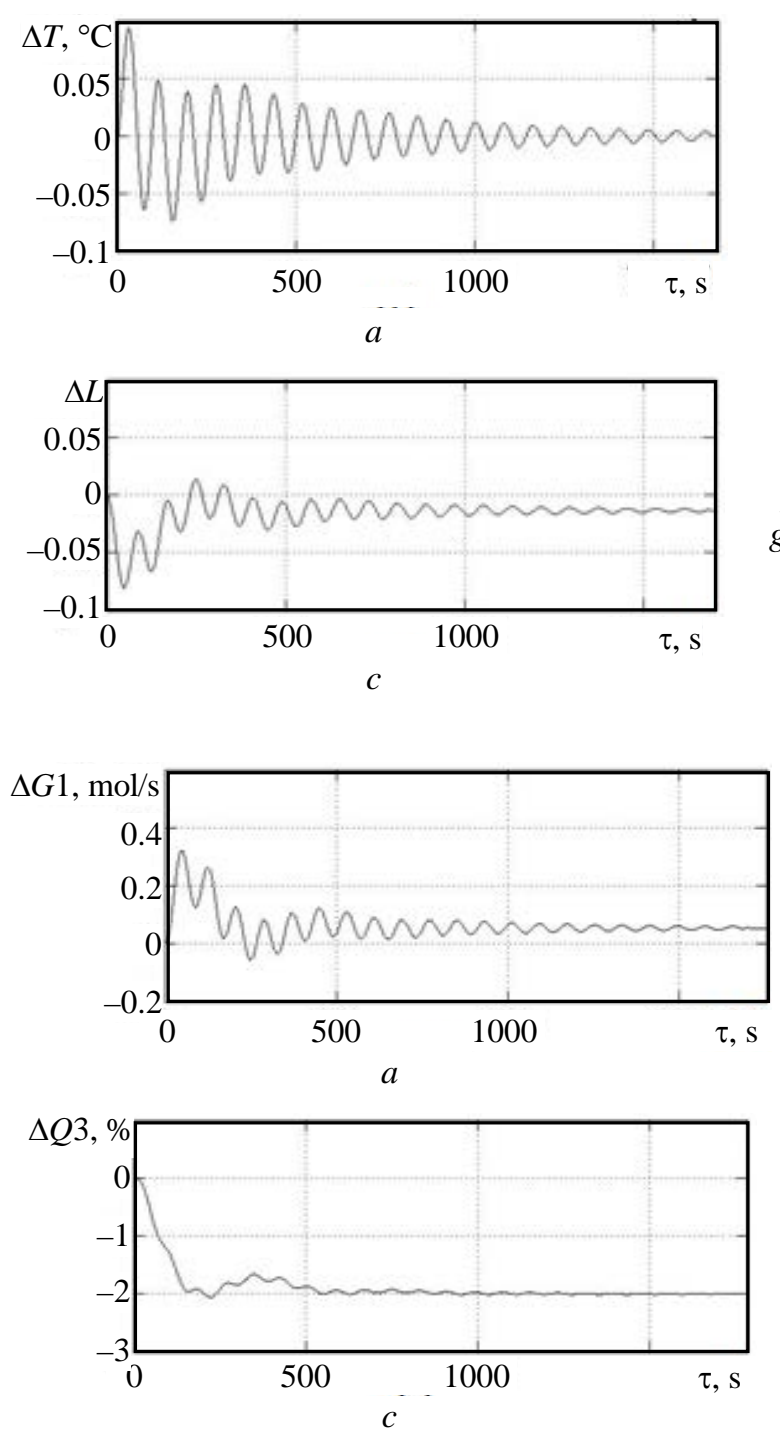

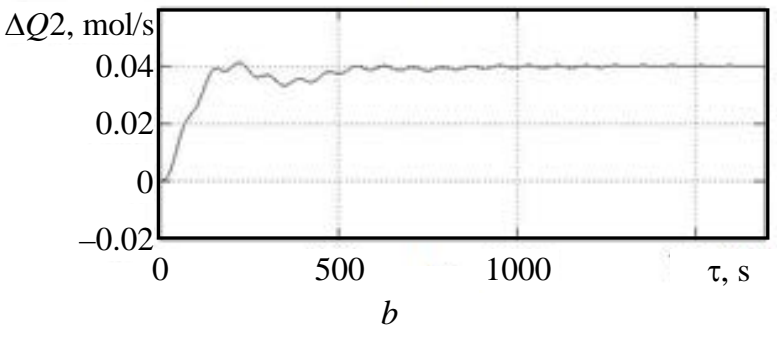

Fig. 5. Deviation of the controlled parameters of the pyrolysis facility from time: temperature of the product gas (a); consumption of the product gas (b); composition of the product gas $(c)$

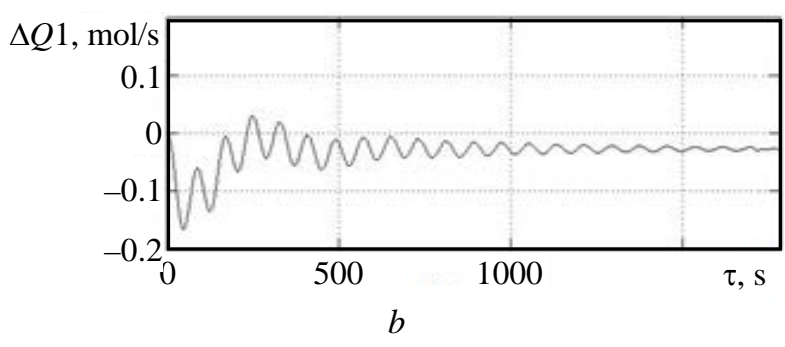

Fig. 6. Deviation of the regulatory effects of the pyrolysis facility during disturbance: consumption of raw material (a); consumption of air (b); consumption of product gas recirculation (c)

To calculate the efficiency of each structure $\eta_{e f ~}^{j}$, it is necessary, in addition to the need for electrical energy $N(\tau)$, to know the energy gross costs $\varphi$, which are defined in $[4,5]$

Let's consider possible structures of a bioten power plant for which it is necessary to compose a vector of initial data.

Structure I. Only the bioreactor works in the plant in the stationary mode, the fermented residue enters the storage, and the obtained biomethane is sent to the gas holder, the gas diesel constantly generates electric energy, the cooling of the diesel is spent on the preparation and heating of the initial substrate. The vector of initial data for structure I has the form

$$
\bar{l}_{\mathrm{I}}=\left(N_{D G F}^{\max }, \eta_{D G F}\left(N_{D G F}\right), N_{D G F}^{\min }, N_{D G F} ; \eta_{e f}\right) \text {. }
$$

Structure II. The bioreactor operates in the plant in a stationary mode and the pyrolysis unit is in a controlled dynamic range, the fermented residue enters the storage, and then undergoes pyrolysis. The resulting biomethane and gas product from the pyrolysis facility is sent to the gas holder. Carbonaceous residue and resins arrive at the warehouse. By regulating the operation of the pyrolysis unit, the generation of electric energy in a gas diesel changes $N_{D G F}$ and $N_{D G F}^{p g}$, the cooling of the diesel is 
spent on preparing and heating the initial substrate and draining the fermented residue. The vector of initial data for structure II has the form:

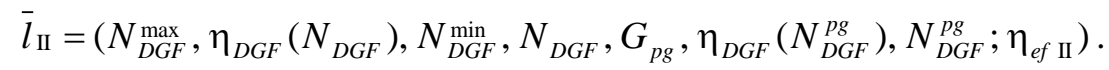

Table 1

The initial data

\begin{tabular}{|c|c|}
\hline Name of indicator & Indicator value \\
\hline Yield of corn (mt/ha) & 15 \\
\hline Obtained biomethane, $\mathrm{kg}$ & 238 \\
\hline Calorific value of biomethane, $\mathrm{MJ} / \mathrm{kg}$ & 35.5 \\
\hline Obtained fermented residue, $\mathrm{kg}$ & 374 \\
\hline Obtained product gas, kg & 261.8 \\
\hline Calorific value of product gas, MJ/kg, & 20 \\
\hline Obtained liquid fuel, kg & 56.1 \\
\hline Calorific value of liquid fuel, MJ/kg, & 23 \\
\hline Obtained carbonaceous residue, $\mathrm{kg}$ & 56.1 \\
\hline Calorific value of carbonaceous residue, $\mathrm{MJ} / \mathrm{kg}$ & 30 \\
\hline The maximum efficiency of the diesel generator facility & 0.46 \\
\hline The maximum efficiency of the steam turbine facility & 0.42 \\
\hline $\begin{array}{l}\text { Minimum capacity of diesel generator facility on bioten } \\
\text { methane, MW }\end{array}$ & 3.88 \\
\hline Added power of diesel generator facility on product gas, MW & 2.41 \\
\hline $\begin{array}{l}\text { Мінімальна потужність паро-турбинної установки на вуг- } \\
\text { листому залишку, MW }\end{array}$ & 0.35 \\
\hline $\begin{array}{l}\text { The minimum power of the steam turbine facility on the carbon } \\
\text { residue, MW }\end{array}$ & 0.71 \\
\hline $\begin{array}{l}\text { Power of a virtual power plant on liquid fuel that provides } \\
\text { torque, MW }\end{array}$ & 0.54 \\
\hline Torque reserve, $\mathrm{MW}$ & 0.08 \\
\hline Gross costs for basic electricity, $\mathrm{J}(\mathrm{h}) / \mathrm{J}(\mathrm{e})$ & 3.233888889 \\
\hline Gross costs for peak electricity, J(h)/J(e) & 5.352777778 \\
\hline Simulation time lapse $\tau, \mathrm{s}$ & 28800 \\
\hline A polynomial, by which set a systemic demand $N(\tau)$, MW & $-0.0001 \tau^{2}+0.3923 \tau+0.3552$ \\
\hline $\begin{array}{l}\text { A polynomial, by which set dynamic properties of pyrolysis } \\
\text { product-gas facility } G_{p g}(\tau), \mathrm{kg} / \mathrm{s}\end{array}$ & $-0.0006 \tau^{2}+0.5505 \tau+0.1331$ \\
\hline $\begin{array}{l}\text { A polynomial, by which set dynamic properties of increase / } \\
\text { decrease of power DGF } N_{D G F}(\tau) \text {, MW }\end{array}$ & $\begin{array}{l}-0.7917 \tau^{2}+112.285 \tau \\
-0.7917 \tau^{2}-17.27 \tau+3886.7\end{array}$ \\
\hline $\begin{array}{l}\text { A polynomial, by which set dynamic properties of increase / } \\
\text { decrease of power STF } N_{S T F}(\tau) \text {, MW }\end{array}$ & $\begin{array}{l}0.0001 \tau^{2}+0.3923 \tau+0.3552 \\
0.0001 \tau^{2}+0.0923 \tau+718.65\end{array}$ \\
\hline $\begin{array}{l}\text { A polynomial, by which set dynamic properties of increase / } \\
\text { decrease of capacity virtual power plant } N_{\text {VirPP }}(\tau) \text {, MW }\end{array}$ & $\begin{array}{l}0.0022 \tau^{2}+1.8438 \tau+0.3559 \\
0.0022 \tau^{2}+0.3 \tau+718.65\end{array}$ \\
\hline The maximum value of disturbances, MW & $10 ; 7$ \\
\hline
\end{tabular}

Structure III. The plant has a bioreactor in stationary mode and a pyrolysis unit and a steam turbine facility in adjustable dynamic ranges, the fermented residue enters the storage, and then undergoes pyrolysis. The resulting biomethane and product gas from the pyrolysis unit is sent to the gas holder. Carbonaceous residue and resins arrive at the warehouse, and then sent to STF. Regulating the operation of the pyrolysis units and the steam turbine, the generation of electric energy in a gas diesel engine changes $N_{D G F}$ and $N_{D G F}^{p g}$ and additionally, the generation of electric energy changes STF $N_{S T F}$. 
Diesel generator cooling and STF spent on preparation and heating of the initial substrate and drainage of the fermented residue. The initial data vector for structure III has the form:

$$
\bar{l}_{\text {III }}=\left(N_{D G F}^{\max }, \eta_{D G F}\left(N_{D G F}\right), N_{D G F}^{\min }, N_{D G F}, G_{p g}, \eta_{D G F}\left(N_{D G F}^{p g}\right), N_{D G F}^{p g}, N_{S T F}^{\max }, \eta_{S T F}\left(N_{S T F}\right), N_{S T F}^{\min }, N_{S T F} ; \eta_{e f} \text { III }\right)
$$

Structure IV. The plant has a bioreactor in stationary mode and a pyrolysis unit and a steam turbine facility in adjustable dynamic ranges. At the STF is foreseen not the maximum load, but a part of the power is reserved for the rotating reserve. From the bioreactor, the fermented sediment enters the storage, and then undergoes pyrolysis. The obtained biomethane and product gas from the pyrolysis unit is sent to the gas tank.

Carbonaceous residue and resins arrive at the warehouse and then sent to the STF. Regulating the operation of the pyrolysis units and the steam turbine, the generation of electric energy in a gas diesel engine changes $N_{D G F}$ and $N_{D G F}^{p g}$ and additionally, the generation of electric energy changes at the STF $N_{\text {STF }}$, while STF is not loaded to a maximum value, but has a power reserve for a rotating reserve $N_{\text {VirPP }}$.

The cooling of the diesel generator and STF is spent on preparing and heating the initial substrate and draining the fermented residue. The initial data vector for structure IV has the form:

$$
\begin{aligned}
\bar{l}_{\mathrm{IV}}=\left(N_{D G F}^{\max }, \eta_{D G F}\left(N_{D G F}\right),\right. & N_{D G F}^{\min }, N_{D G F}, G_{p g}, \eta_{D G F}\left(N_{D G F}^{p g}\right), N_{D G F}^{p g}, N_{S T F}^{\max }, \eta_{S T F}\left(N_{S T F}\right), N_{S T F}^{\min }, N_{S T F}, \\
& \left.N_{\text {VirPP }}^{\max }, \eta_{\text {VirPP }}\left(N_{\text {VirPP }}\right), N_{\text {VirPP }}^{\min }, N_{\text {VirPP }} ; \eta_{\text {ef IV }}\right) .
\end{aligned}
$$

The calculation of each structure is carried out separately according to the algorithm for calculating the efficiency indicator. The developed algorithm contains: input conditions and a search algorithm.

Input conditions.

A. For analysis the following data were accepted for power system consumption: function of energy consumption depending on time $N(\tau)$; its minimum $N_{\text {min }}$ and maximum $N_{\text {max }}$ values, and the system demand is calculated by the formula $\int_{0}^{\tau_{\text {est }}} N(\tau) d \tau$.

B. Data on the bioten power plant. The consumption of the initial substrate (corn) and the amount of biomethane produced from it $G_{b m}$ with its calorific value $G_{b m}$ and the fermented residue formed from it $G_{f r}$.

C. The dynamic characteristic of the product gas flow $G_{p g}(\tau)$ of the pyrolysis unit, the accelerating characteristics of the diesel generator $N_{D G F}(\tau)$ and steam turbine facility $N_{S T F}(\tau)$, virtual power plant using a rotating reserve $N_{\text {VirPP }}(\tau)$.

D. Limit values of the energy characteristics of the plants: for diesel generator $-N_{D G F}^{\min }$ and $N_{D G F}^{\max }$, for steam turbine $-N_{S T F}^{\min }$ and $N_{S T F}^{\max }$, for virtual $-N_{\text {VirPP }}^{\min }$ and $N_{\text {VirPP }}^{\max }$.

E. Adjustable characteristics: for a pyrolysis installation for the consumption of product gas $G_{p g}(\tau) \in\left[0 ; G_{p g}^{\max }\right]$; for DGF $-N_{D G F} \in\left[N_{D G F}^{\min } ; N_{D G F}^{\max }\right]$; for STF $N_{S T F} \in\left[N_{S T F}^{\min } ; N_{S T F}^{\max }\right]$, for virtual power plant $-N_{\text {VirPP }} \in\left[N_{\text {VirPP }} ; N_{\text {VirPP }}\right]$.

F. Regulation conditions for power plants of the inflicted perturbation $\Delta N_{p}$, in the range $\Delta N_{p} \in\left(0 ;\left(N_{S T F}^{\max }+N_{D G F}^{\max }\right)-N\left(\tau_{i}\right)\right]$.

1. DGF and STF work in parallel in order to compensate for the inflicted perturbation as quickly as possible:

$$
\text { if } N_{D G F}\left(\tau_{i}\right)+N_{S T F}\left(\tau_{i}\right)<N_{D G F}^{\max }+N_{S T F}^{\max } \text {, that } N_{\text {VirPP }}\left(\tau_{i}\right)=0 \text {. }
$$

2. Virtual power plant compensates inflicted perturbation provided $N_{D G F}\left(\tau_{i}\right)+N_{S T F}\left(\tau_{i}\right) \geq N_{D G F}^{\max }+N_{S T F}^{\max }$. 
3. The values of the efficiency of STF, DGF and virtual plant depend on current power: $\eta_{S T F}\left(N_{S T F}\left(\tau_{i}\right)\right), \quad \eta_{D G F}\left(N_{D G F}\left(\tau_{i}\right)\right)$ and $\eta_{V i r P P}\left(N_{V i r P P}\left(\tau_{i}\right)\right)$ and is determined from the formula $\eta() \tau_{i}=\eta_{\max }\left(\frac{N\left(\tau_{i}\right)}{N_{\max }}\right)^{0.37}$.

4. The imbalance of the current state at the time point of the system is calculated by the formula $\varepsilon N\left(\tau_{i}\right)=N\left(\tau_{i}\right)-\left(N_{D G F}\left(\tau_{i}\right)+N_{S T F}\left(\tau_{i}\right)\right)$.

G. Energy characteristics: biomethane $-Q_{b m}$, product gas $-Q_{p g}$, carbonaceous residue $-Q_{c r}$ and resin $-Q_{r}$.

$\mathbf{H}$. The calculation of the efficiency of the current structure of units of power equipment at a time $\tau_{\text {est }}$ will be carried out according to the formula

$$
\eta_{\text {ef }}=\frac{\int_{0}^{\tau_{\text {est }}} N(\tau) d \tau}{\int_{0}^{\tau_{\text {est }}}\left(\frac{N_{S T F}(\tau)}{\eta_{S T F}\left(N_{S T F}(\tau)\right)}+\frac{N_{D G F}(\tau)}{\eta_{D G F}\left(N_{D G F}(\tau)\right)}+\frac{N_{\text {VirPP }}(\tau)}{\eta_{\text {VirPP }}\left(N_{\text {VirPP }}(\tau)\right)}+\varepsilon N(\tau) \cdot \varphi\right) d \tau},
$$

where $\varphi$ - are the closing energy costs determined in $[4,5]$.

The search algorithm is in the time cycle by $\tau \in\left[0 ; \tau_{\text {est }}\right]$.

Step 1.

We determine the initial values of all technological parameters of power plants to ensure the initial conditions.

Step 2.

The current value of the system demand without disturbance is calculated according to paragraph A of the input conditions. Inflicted perturbation to the system at a point in time $\tau_{i}$ taken into account by changing the rule for calculating system requirements, namely, on the time interval of the perturbation, the current value of the system demand is taken as

$$
\int_{0}^{\tau_{i}} N(\tau) d \tau+N_{\max }\left(\tau_{e s t}-\tau_{i}\right) .
$$

Step 3.

Compare the minimum power settings $N_{D G F}^{\min }$ with the current value of the system demand $N\left(\tau_{i}\right)$. If the value of the system demand is more or less, then we change the structure of technical means, connecting or disconnecting accordingly pyrolysis plant according to paragraph $\mathrm{C}$ of input conditions.

Step 4.

Compare the sum of the current power values of the two plants $N_{D G F}\left(\tau_{i}\right)+N_{S T F}\left(\tau_{i}\right)$ with the current value of the system demand $N\left(\tau_{i}\right)$. If the values are equal, then control actions are not applied. If the value of the sum is more or less, then the control actions decrease or increase, respectively, according to paragraph $\mathrm{C}$ of the input conditions.

Step 5.

Compare the sum of the maximum power values of the two plants $N_{D G F}^{\max }+N_{S T F}^{\max }$ with the current value of the system demand $N\left(\tau_{i}\right)$. If the value of the sum is less or more, then we change the structure of the technical means by connecting or disconnecting the virtual installation accordingly according to paragraph $\mathrm{C}$ of the input conditions.

Step 6. 
We determine the imbalance $\varepsilon N\left(\tau_{i}\right)$ between the generating units and the system demand in accordance with paragraph $\mathrm{F}$ of the initial conditions of clause 4 .

Step 7.

We calculate the efficiency according to paragraph $\mathrm{H}$ of the initial conditions.

The choice of the best structure corresponds to the maximum value of the efficiency coefficient: $\eta_{\text {ef } \max }=\max \left\{\eta_{\text {ef II }} ; \eta_{\text {ef II }} ; \eta_{\text {ef III }} ; \eta_{\text {ef IV }}\right\}$.

\section{Discussion of the results}

Vector calculations $\bar{l}_{\mathrm{I}} ; \bar{l}_{\mathrm{II}} ; \bar{l}_{\mathrm{III}} ; \bar{l}_{\mathrm{IV}}$ gave the following results, according to [3, 4,]: $\eta_{\text {ef } \max }=\max \{0.293671 ; 0.401699 ; 0.403515 ; 0.411219\}=0.411219$. Thus, structure IV is best. Subsequently, the structure of IV was studied taking into account the amendments in the schedule of systemic needs. Table 2 shows polynomials, simulations of system demand and value $\eta_{e f}$.

Table 2

The results of modeling

\begin{tabular}{l|l|c}
\hline Type of polynomial simulation & Polynomial simulation & Efficiency indicator $\eta_{\text {ef }}$ \\
\hline Linear & $595 \tau+4239.97$ & 0.411219 \\
\hline Square convex & $-72.74 \tau^{2}+1177 \tau+4239.97$ & 0.397023 \\
\hline Quadratic concave & $74 \tau^{2}+3.1 \tau+4239.97$ & 0.400392 \\
\hline Quadratic with extremum & $-125.85 \tau^{2}+1548.5 \tau+4239.97$ & 0.388476 \\
\hline
\end{tabular}

At Fig. 7 dependencies of changes in the energy efficiency indicator $\eta_{e f}$ are shown for various types of system demand schedules according to Table 2 depending on time. In the given dependences, two groups of changes $\eta_{e f}$ can be highlighted: the first spasmodic ones illustrating a change in the structure of a power plant at some point of time $\tau$ and leading to a local increase $\eta_{\text {ef }}$; the second smooth ones are explained in the unchanged structure by the amendment in the adjustable parameters by the regulators.

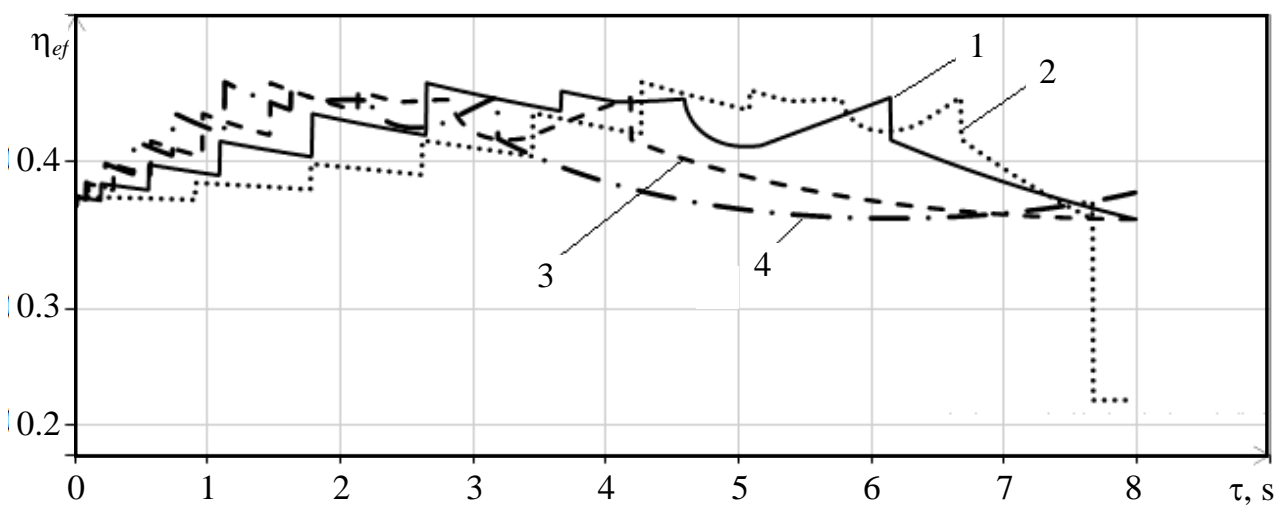

Fig. 7. Dependencies of the energy efficiency indicator amendments for different types of system time graphs. (For the type of system need dependence, check A of the initial conditions: 1 - linear; 2 - concave; 3 - convex; 4 - with extremal)

The main conclusion that the considered method allows to control not only the structure of power plants that make up the bioten, but also control the technological parameter. In addition, the analysis of changes $\eta_{e f}$ from $\tau$ for various types of adjustments in systemic needs showed that in the curves a transformable similarity of the found solutions for managing the structure is observed. The shift of the 
transformable similarity to the beginning or to the end of the count $\tau$ is related to the current maximum need of the system. It should be noted that a decrease in indicators $\eta_{e f}$ at the beginning or at the end of the reference is associated with a small or large systemic need for the considered model. At the beginning of the countdown in a bioenergy plant, only one of the plants in the structure generates electricity, but with a reduced own efficiency due to the fact that the maximum power of this plant exceeds the system demand, and in the end all the plants operate at maximum power, but still there is a lack of power and it offset by locked energy costs. The same lack of power is happening when perturbing.

For research of revealed circumstance with structure IV for linear systemic needs, computational experiments were carried out related to the application of spasmodic perturbations of power. Perturbations (check Table 1) were caused by two different values of $10 \mathrm{MW}$ with a significantly larger value than the system demand and $7 \mathrm{MW}$ with a value commensurate with the maximum value of the system demand) over a time interval $\left[\tau_{p} ; 28800\right]$ sec at $\tau_{p} \in\{18 ; 5400 ; 12600 ; 19800 ; 27000\}$.

The results of computational experiments are shown in Fig. 8 and Fig. 9.

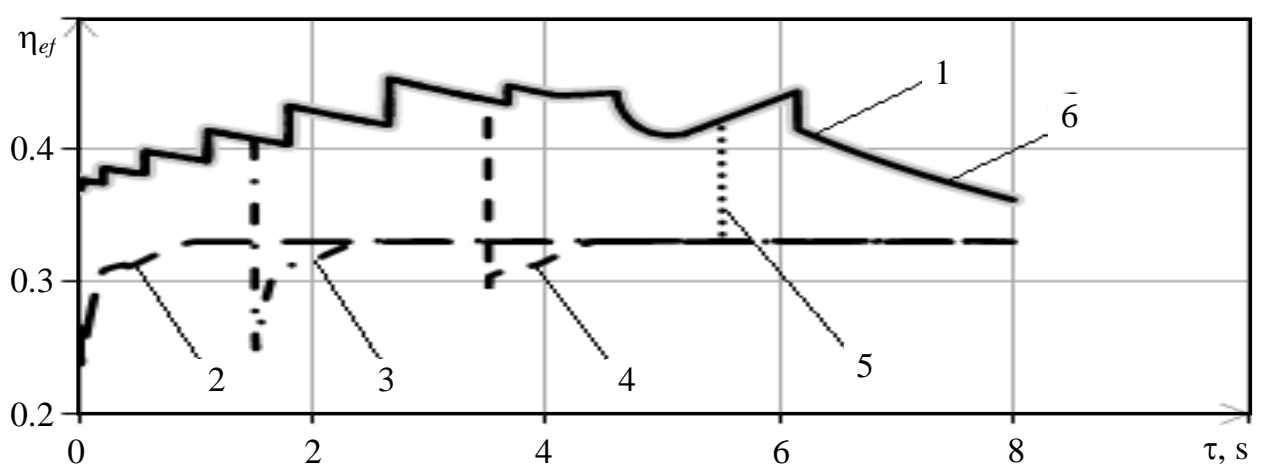

Fig. 8. Dependences of the change of the energy efficiency indicator for the case of perturbation with a power jump of $10 \mathrm{MW}$. (1 - no perturbation; 2 - perturbation after 0.05 hours; 3 - perturbation after 1.5 hours; 4 perturbation after 3.5 hours, 5 - perturbation after 5.5 hours; 6 - perturbation after 7.5 hours ).

An analysis of the results showed that when a perturbation is applied by a power jump to the plant, the efficiency index sags, and then, by amendment of the structure, its relatively increase. This effect is observed with small system needs, when there is an energy potential to compensate for disturbances, but this effect ceases to be observed when the system demand is commensurate with the maximum plant power.

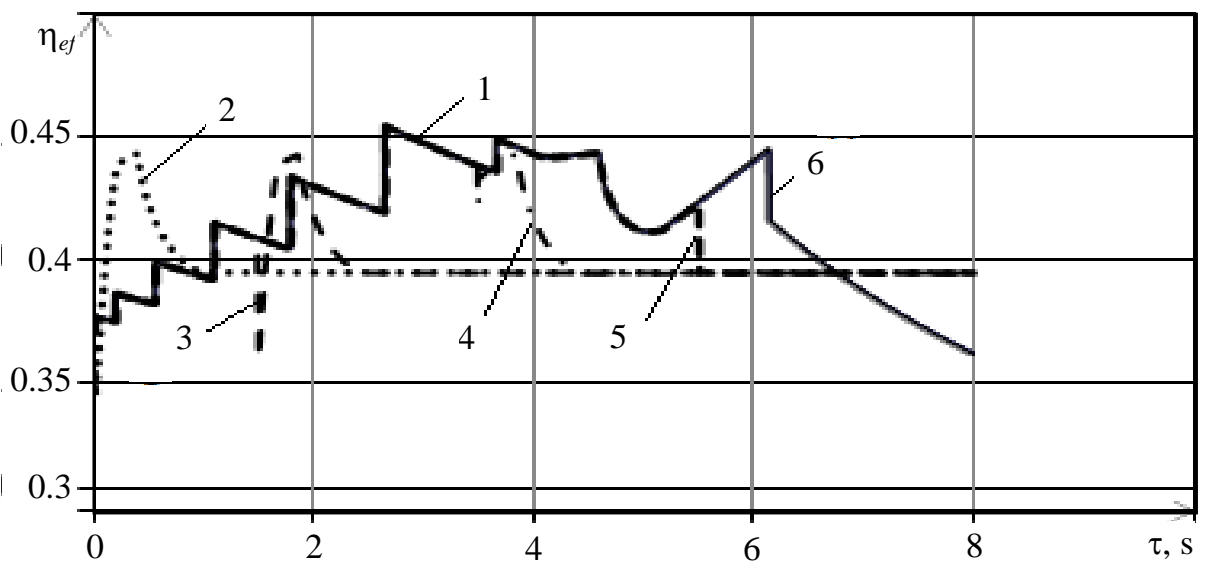

Fig. 9. Dependences of the change of the energy efficiency indicator for the case of disturbance with a power jump of 7 MW at different times: (1 - no disturbance; 2 - disturbance in 0.05 hours; 3 - disturbance in 1.5

hours; 4 - disturbance in 3.5 hours, 5 - indignation after 5.5 hours; 6 - indignation after 7.5 hours) 
A confirmation of this hypothesis was demonstrated in the case of perturbation by a power jump equal to the maximum system demand. From the analysis of the figure, we can conclude that only a amendments in the structure of the system is carried out to compensate for the disturbance.

\section{Conclusions}

1. Synthesized automated control system of the pyrolysis plant, which allows to stabilize the technological process of obtaining the product-gas at the set technological values and developed a method of controlling the pyrolysis of organic raw materials to ensure a given consumption of product-gas in the application of perturbations with the composition of raw material.

2. An analysis method is developed, which determines the suitability of power plants of different types, depending on their dynamic characteristics, for the possibility of compensation of disturbances in the energy system. A method of finding the best structure of a biotank power plant is developed by determining the objective function of optimization and finding structural combinations of a power plant using renewable energy sources that have the properties of regulation, depending on external perturbations in order to maintain the balance of the energy system.

3. As a result of the development of CICS by bioten technology, the best structure of power plants was determined. This structure consists of a bioreactor operating in a stationary mode, pyrolysis and technical training units operating in controlled dynamic ranges. The resulting biomethane and product gas from the pyrolysis unit is sent to a gas tank and then to DGF. Carbonaceous residue and resins arrive at the warehouse, and then sent to STF. By regulating the operation of the pyrolysis units and the steam turbine, the generation of electric energy $N_{D G F}$ and $N_{D G F}^{p g}$ on a gas diesel engine changes and the generation of electric energy on a STF $N_{\text {STF }}$ also changes, while the STF is not loaded to its maximum value, but has a power reserve for a rotating reserve $N_{\text {VirPP }}$, the efficiency indicator is following: $\eta_{\text {ef } \max }=\max \{0.293671 ; 0.401699 ; 0.403515 ; 0.411219\}=0.411219$.

\section{Література}

1. Никулина Е.Н., Северин В.П. , Николаенко Т.Е. Модификация генетических алгоритмов для оптимизации векторных целевых функцій. Вісник Національного технічного університету «Харківський політехнічний інститут» серія: Системний аналіз, управління та інформачійні технологіï. 2013. № 3 (977). С. 9-14.

2. Северин В.П., Никулина Е.Н., Чеченова И.Х. Нелинейные модели переходных режимов паровых турбин АЭС для оптимизации процессов управления. Вісник Національного технічного університету «Харківський політехнічний інститут» серія: Енергетичні та теплотехнічні прочеси й устаткування. 2016. № 8 (1180). С. 65-71.

3. Верхикер Г.П. О термодинамическом сравнении и анализе схем энергетических технологических установок. Высшие учебные заведения «Известия». Сер.: Энергетика. 1986. 11. 90-93.

4. Максимова О.Б., Максимов М.М., Силина В.С., Орищенко А.В. Разработка метода определения целевой функции оптимизации электростанции. Автоматизация технологических и бизнес проиессов. 2017. Том 9, Вып. 2. 28-35.

5. Максимова О.Б., Максимов М.М., Силина В.С., Орищенко А.В. Анализ эффективности баланса энергосистемы, обеспечиваемого различными группами генерирующих электростанций. Автоматизация технологических и бизнес процессов. 2017. 10, 4. 47-55.

6. Maksimov M., Davydov V., Krusir G., Maksimova O. Increasing of process efficiency of biogas plants production processing. Праиі Одеського політехнічного університету. 2017. 3 (53). P. 43-53. DOI: 10.15276/opu.3.53.2017.06.

7. Лысюк А.В., Беглов К.В. Автоматизация распределения нагрузки между параллельно работающими котлами. Автоматизаџия технологических и бизнес-процессов. 2017. Том 9, № 3, С. 15-22.

8. Северин В.П., Никулина Е.Н., Чернай В.Ф., Годлевская К.Б. Многоцелевой синтез нелинейных систем управления паровой турбиной АЭС по прямым показателям качества. Энергосбережение. Энергетика. Энергоаудит. Специальный выпуск. 2013. Том 2. № 8 (114). С. 134-140.

9. Никулина Е.Н. Северин В.П., Реуцкая М.В. Модель для параметрического синтеза электронной части следящего привода. Вісник Національного технічного університету «Харківський політех- 
нічний інститут» (серія: Системний аналіз, управління та інформаційні технологї). 2013. № 2 (976). С. 7-12.

10. Nikulina E.N., Severyn V.P., Kotsiuba N.V. Optimization of direct quality indexes of automatic control systems of steam generator productivity. Вісник Національного технічного університету «Харківський політехнічний інститут» (серія: Системний аналіз, управління та інформаційні технолоziii). 2018. № 21 (1297). C. 8-13.

11. Фильтрационное горение системы углерод - инертный материал в режиме со сверхадиабатическим разогревом / Е.А. Салганский, В.М. Кислов, С.В. Глазов и др. Физика горения и взрыва. 2008. T. XLIV. № 3. C. 30-38.

12. Kositsyn V.Y., Rybalev A.N., Telichenko D.A. A system for controlling the boiler heat load. Thermal Engineering. 2013. T. 60. № 2. C. 130-136.

\section{References}

1. Nikulina, E.N., Severin, V.P., \& Nikolaenko, T.E. (2013). Modification of genetic algorithms for optimization of vector target functions. Bulletin of the National Technical University «Kharkiv Polytechnic Institute» (series: System analysis, management and information technology), 3 (977), 9-14.

2. Severin, V.P., Nikulina, E.N., \& Chechenova, I.H. (2016). Nonlinear Transient Models of NPP Steam Turbines for Optimization of Control Processes. Bulletin of the National Technical University «Kharkiv Polytechnic Institute» (series: Energy and thermal engineering processes and equipment), 8 (1180), 65-71.

3. Verhiker, G.P. (1986). On thermodynamic comparison and analysis of circuits of power technological plants. Higher educational institutions of Izvestia. Ser.: Energy, 11, 90-93.

4. Maksimova, O.B., Maksimov, M.M., Silina, V.S., \& Orischenko, A.V. (2017). Development of a method for determining the objective function of a power plant optimization. Automation of technological and business processes, 9, 2, 28-35.

5. Maksimova, O.B., Maksimov, M.M., Silina, V.S., \& Orischenko, A.V. (2017). Analysis of the balance efficiency of the power system provided by different groups of generating power plants. Automation of technological and business processes, 10, 4, 47-55.

6. Maksimov M., Davydov V., Krusir G., \& Maksimova O. Increasing the process efficiency of biogas plants production processing. Proceedings of Odessa Polytechnic University, 3 (53), 43-53. DOI: 10.15276/opu.3.53.2017.06.

7. Lysyuk, A.V., \& Beglov, K.V. (2017). Automation of load distribution between boilers running in parallel. Automation of technological and business processes, 9, 3, 15-22.

8. Severin, V.P., Nikulina, E.N., Chernaya, V.F., \& Godlevskaya, K.B. (2013). Multi-purpose synthesis of non-linear steam turbine Control Systems for NPPs on Direct Quality Indicators. Energy Saving. Energy. Energy audit. Special issue, 2, 8 (114), 134-140.

9. Nikulina, E.N., Severin, V.P., \& Reutskaya, M.V. (2013). Model for parametric synthesis of the electronic part of the tracking drive. Bulletin of the National Technical University «Kharkiv Polytechnic Institute» (series: System analysis, management and information technology), 2 (976), 7-12.

10. Nikulina, E.N., Severyn, V.P., \& Kotsiuba, N.V. (2018). Optimization of direct quality indexes of automatic control systems of steam generator productivity. Bulletin of the National Technical University «Kharkiv Polytechnic Institute» series: System analysis, management and information technologies, 21 (1297), 8-13.

11. Salgansky, E.A., Kislov, V.M., \& Glazov, S.V. et al. (2008). Filtration combustion of the carbon system - an inert material in the regime with super diabatic heating. The physics of combustion and explosion, $X L I V, 3,30-38$.

12. Kositsyn, V.Y., Rybalev, A.N., \& Telichenko, D.A. (2013). A system for controlling the boiler heat load. Thermal Engineering, 60, 2, 130-136.

Максимов Максим Максимович; Maksymov Maksym, ORCID: http://orcid.org/0000-0002-5626-5265

Беглов Костянтин Вячеславович; Beglov Konstantin, ORCID http://orcid.org/0000-0002-5277-2577

Максимова Оксана Борисівна; Maksymova Oksana, ORCID: http://orcid.org/0000-0003-3986-0991

Максимов Олексій Максимович; Maksymov Oleksiy, ORCID: https://orcid.org/0000-0003-2504-0853 